\title{
Bacterial viruses in coastal seawater: lytic rather than lysogenic production
}

\author{
Robin M. Wilcox, Jed A. Fuhrman* \\ Department of Biological Sciences, University of Southern California, Los Angeles, California 90089-0371, USA
}

\begin{abstract}
It has recently been suggested that the majority of virus production in seawater is through lysogen induction. Here, we examine the mechanism of virus production in coastal surface seawater. Bacteria and viruses were removed from seawater by ultrafiltration $(0.2$ or $0.02 \mu \mathrm{m})$ and introduced back to the water in $0.6 \mu \mathrm{m}$ filtered inocula. Viral and bacterial abundance was followed during sample incubations using transmission electron microscopy and acridine orange direct counts. Bacteria increased in abundance in all cases. When initial abundances were less than $1.3 \times 10^{6}$ viruses $\mathrm{ml}^{-1}$, (with extremely low initial bacterial densities), viruses disappeared at a rate of 20 to $50 \% \mathrm{~d}^{-1}$ for the first $2 \mathrm{~d}$ and did not increase in abundance over the $7 \mathrm{~d}$ incubation period. Continuous sunlight exposure or a pulse of sunlight did not lead to detectable virus production, indicating that natural UV light did not induce lysogens. In samples with initial abundances above $1.3 \times 10^{6}$ viruses $\mathrm{ml}^{-1}$, significant increases as well as fluctuations in virus numbers were observed after the second day. This suggests that lytic infection, rather than the induction of lysogenic bacteria, is responsible for the majority of bacteriophage production in these experiments. Since lytic infection is dependent on encounter frequency, which is controlled by densities of both viruses and bacteria, the product of these 2 concentrations determines if infection may take place. We observed lytic infection only when the product of virus and bacteria numbers equalled $10^{12}$ or more. Reported abundances of viruses and bacteria in natural seawater samples frequently fall above this level in surface waters and below it in mid and deep waters, suggesting that lytic infection may occur in all but deeper waters. However, due to the specificity of host/virus interactions, infection is also dependent on the quantitative bacterial species composition and diversity, which are presently unknown.
\end{abstract}

KEY WORDS: Bacterioplankton · Virus · Infection · Phage - Lysogeny · Lysis

\section{INTRODUCTION}

Recent studies have shown viruses to be abundant $\left(10^{4}\right.$ to $10^{8}$ viruses $\left.\mathrm{ml}^{-1}\right)$ in marine environments (e.g. Torrella \& Morita 1979, Proctor et al. 1988, Bergh et al. 1989, Børsheim et al. 1990, Proctor \& Fuhrman 1990, Wommack et al. 1992, Cochlan et al. 1993, Paul et al. 1993). Measurements of viral disappearance rates (Heldal \& Bratbak 1991) and decay of infectivity (Spencer 1960, Suttle \& Chen 1992, Suttle et al. 1992, Fuhrman \& Suttle 1993, Fuhrman et al. 1993) have indicated that marine viral communities are dynamic, with decay rates of up to $1.1 \mathrm{~h}^{-1}$ (Heldal \& Bratbak

-Addressee for correspondence
1991). Observations of the high abundances of bacteria in seawater (e.g. Ferguson \& Rublee 1976, Hobbie et al. 1977), and of a significant proportion of bacteria infected with mature viral particles (Proctor \& Fuhrman 1990, 1991, Heldal \& Bratbak 1991), have led to speculations that the majority of viral host organisms in the marine environment are bacteria and that bacterial viruses are responsible for a large amount of bacterial mortality (Proctor \& Fuhrman 1990, Heldal \& Bratbak 1991). This has implications for nutrient cycling and trophic relations in the microbial food web (Bratbak et al. 1990, Proctor \& Fuhrman 1991, Fuhrman 1992, Fuhrman \& Suttle 1993).

There are 3 mechanisms of virus replication (Ackermann \& DuBow 1987). (1) The lytic cycle involves infection of the host organism, subsequent replication 
of viruses within it, and release of viral progeny from the lysed host. Further replication requires the infection of another host. Temperate viruses are replicated either through the lytic cycle or lysogeny. (2) In lysogeny, viral nucleic acid is replicated simultaneously with the host chromosome after initial infection. The viral nucleic acid can remain dormant for several generations within the host until induction of lytic growth by an environmental factor such as ultraviolet light or nutrient depletion. (3) Chronic infections do not involve lysis of the host. Rather, the mature viruses are produced in actively growing hosts and are released to the environment by budding or filament extrusion. The relative importance of each mechanism in seawater is currently unknown and subject to speculation.

It has been shown that decay of viral infectivity occurs rapidly in surface waters (reviewed in Kapuscinski \& Mitchell 1980, Suttle \& Chen 1992) and that, for each bacterial host examined, there are relatively few viable viruses per milliliter of seawater (Spencer 1960, Moebus 1987, 1992). In many cases, host/virus density may be below the minimum required to initiate infection. Wiggins \& Alexander (1985) found a minimum host density of $10^{4}$ colony-forming units (CFU) $\mathrm{ml}^{-1}$ was required for bacteriophage replication in lab cultures of Staphylococcus aureus. This sort of observation has led to the suggestion that most marine viruses are temperate, lying dormant within their hosts, and that replication is dependent upon rate of lysogen induction rather than rate of infection (Bratbak et al. 1990, 1992, Heldal \& Bratbak 1991, Thingstad et al. 1993). However, Kokjohn et al. (1991) observed bacteriophage replication in Pseudomonas aeruginosa at densities as low as $10^{2} \mathrm{CFU} \mathrm{ml} \mathrm{m}^{-1}$. Presently bacterial abundance in natural seawater samples is determined through direct epifluorescence microscopic counts using fluorescent stains such as acridine orange and has been found to be ca $10^{6} \mathrm{ml}^{-1}$ in upper seawater (Hobbie et al. 1977). Unfortunately, we do not know the bacterial species present in these communities or their overall diversity. However, given the high abundances of bacteria found, it is probable that several species are present at levels $>10^{2} \mathrm{ml}^{-1}$. Also, we cannot directly compare CFU to total counts. Nonetheless, the data suggest that lytic infection may be possible in natural seawater bacterial communities.

We examined the mechanism of bacteriophage replication in the marine bacterial community with a modification of the seawater culture method of Ammerman et al. (1984), which can be used to study growth of freshly derived mixed bacterial assemblages in seawater cultures free of detritus, phytoplankton and zooplankton. Densities of bacteria and viruses were manipulated by 0.2 or $0.02 \mu \mathrm{m}$ filtration of seawater and subsequent inoculation with $0.6 \mu \mathrm{m}$ filtered seawater. Such cultures apparently mimic the morphological diversity of native communities and are probably reasonably representative of bacteria capable of growth on natural dissolved organic matter (Ammerman et al. 1984). Bacterial and viral abundances were monitored to determine if a viral community could be established by lysogen induction during the growth of bacteria in virus-free seawater, or if a large initial number of viruses is required so that infection and lytic reproduction can occur. We also investigated the minimum bacterial and viral densities required for lytic infection.

\section{MATERIALS AND METHODS}

Sampling. Seawater was collected from surface waters at the Santa Monica Pier, California, USA ( $34^{\circ}$ $0.5^{\prime} \mathrm{N}, 118^{\circ} 29.8^{\prime} \mathrm{W}$ ), on May 4, June 1, July 18, August 24, and September 5, 1993, using a seawater-rinsed plastic bucket. Samples were transported back to the lab in acid-soaked, seawater-rinsed, 31 polycarbonate bottles in dim light. Subsamples for viral and bacterial counts were immediately preserved with $0.02 \mu \mathrm{m}$ filtered formalin ( $2 \%$ final concentration).

Filtering. The seawater was first filtered by gravity through an A-E glass fiber filter (Gelman) to remove suspended sediment and large cells. A small portion of the sample was set aside for use as an inoculum and the rest split for filtering through a $0.02 \mu \mathrm{m}$ inorganic membrane filter (Anodisc, Whatman) to remove all bacteria and viruses, or a $0.2 \mu \mathrm{m}$ inorganic membrane filter to remove all bacteria and some of the viruses. The inoculum was filtered by gravity either once or, in later experiments, twice through a $0.6 \mu \mathrm{m}$ Nuclepore filter to remove protists and, inadvertently, large bacteria.

Incubations. Filtered seawater was transferred to $500 \mathrm{ml}$, clear polyethylene, seawater-rinsed Whirlpak bags and inoculated with the $0.6 \mu \mathrm{m}$ filtered inoculum. Size of inoculum was usually $3 \% \mathrm{v} / \mathrm{v}$, but 10,20 and $30 \%$ inocula were also used in one experiment. Samples were incubated at near seawater temperature $\left(19^{\circ} \mathrm{C}\right)$ for several days. To test for lysogen induction by sunlight, some samples were incubated on the rooftop in a circulating water bath, where full exposure to sunlight for the duration of the experiment was permitted through the Whirlpak bags which, we found by spectrophotometry, passed $70 \%$ or more of the UV and visible light. In one case, a sample was exposed to a 35 min pulse of noontime sunlight, with the $19{ }^{\circ} \mathrm{C}$ incubation temperature maintained. Subsamples $(40 \mathrm{ml})$ for viral and bacterial counts were removed periodically and preserved with $0.02 \mu \mathrm{m}$ filtered formalin $(2 \%$ $\mathrm{v} / \mathrm{v}$ final concentration). 
Virus and bacteria counts. Preserved samples were stored in the dark at $4^{\circ} \mathrm{C}$ for a short period (usually less than 2 d) before they were prepared for counts of viruses. Bacteria were counted immediately after sampling. Bacteria were stained with acridine orange, filtered (0.2 $\mathrm{\mu m}$ Nuclepore) and counted with an epifluorescence microscope (Olympus Vanox $\mathrm{T}$ ) using the method of Hobbie et al. (1977). Viruses were counted by transmission electron microscopy (TEM) using the method of Børsheim et al. (1990). Viruses in $4 \mathrm{ml} \mathrm{sam-}$ ples were sedimented onto charged, formvar-coated grids by ultracentrifugation, with a Beckman SW 50.1 rotor, at $150000 \times \mathrm{g}$. Grids were removed, and the viruses positively stained with $1 \%(\mathrm{v} / \mathrm{v})$ uranyl acetate for $20 \mathrm{~s}$. Viruses were counted at $27000 \times(100 \mathrm{kV})$ with a JEOL JEM-100 CX II transmission electron microscope.

To determine bacterial cell morphologies, photomicrographs were taken from acridine orange slides. The image of the photograph was projected on a screen, and counts of each visually discernible cell-type made.

\section{RESULTS}

\section{Initial viral and bacterial numbers}

Field abundances of viruses were variable, ranging from 1.3 to $4.7 \times 10^{7} \mathrm{ml}^{-1}$ over the 5 mo sampling period. Bacterial concentrations were much lower than viral concentrations, and ranged from 1.2 to $2.8 \times 10^{6}$ $\mathrm{ml}^{-1}$ (Table 1). The $0.02 \mu \mathrm{m}$ filtrations removed viruses and bacteria to undetectable levels below ca $10^{4} \mathrm{ml}^{-1}$. In samples with $3 \%$ inoculations, viruses were reintroduced at levels of $2.1 \pm 0.51 \times 10^{5} \mathrm{ml}^{-1}$ (mean $\pm \mathrm{SD}$ ) and bacteria at $7.1 \pm 3.3 \times 10^{4} \mathrm{ml}^{-1}$. Numbers of viruses and bacteria introduced with the inocula were ca $45 \%$ lower than the corresponding percentage in the whole unfiltered seawater (Table 1, Figs. 1 to 5). This is probably due to removal of viruses and bacteria from the inoculum during the filtration steps (Gerba \& Goyal 1982, Paul et al. 1991).

\section{Viral and bacterial dynamics in dark-incubated samples}

Counts of bacteria in daily subsamples from each incubation demonstrated a rapid repopulation of the water (Figs. 1 to 5 ). In all cases, bacteria grew exponentially for about the first $40 \mathrm{~h}$ after inoculation, reaching concentrations around $5 \times 10^{6} \mathrm{ml}^{-1}$. In experiments in which the inoculum was passed once through a $0.6 \mu \mathrm{m}$ filter, bacterial numbers were sometimes seen to drop rapidly after several days (Figs. 1
Table 1 Viral and bacterial abundances in unfiltered Santa Monica Pier, California, USA, seawater at time of sampling Numbers are means of duplicates \pm 1 SD

\begin{tabular}{|lcc|}
\hline $\begin{array}{c}\text { Date } \\
(1993)\end{array}$ & $\begin{array}{c}\text { Viral abundance } \\
\left(\mathrm{ml}^{-1}\right)\end{array}$ & $\begin{array}{c}\text { Bacterial abundance } \\
\left(\mathrm{ml}^{-1}\right)\end{array}$ \\
\hline Apr 11 & $4.74 \pm 0.04 \times 10^{7}$ & $1.2 \times 10^{6}$ \\
May 4 & $2.27 \pm 0.03 \times 10^{7}$ & $2.54 \pm 0.01 \times 10^{6}$ \\
Jun 18 & $1.61 \pm 0.04 \times 10^{7}$ & $1.45 \pm 0.07 \times 10^{6}$ \\
Aug 24 & $1.29 \pm 0.04 \times 10^{7}$ & $1.41 \pm 0.06 \times 10^{6}$ \\
Sep 5 & $1.92 \pm 0.04 \times 10^{7}$ & $2.77 \pm 0.03 \times 10^{6}$ \\
\hline
\end{tabular}

\& 2). This is attributed to the presence of heterotrophic flagellates which were observed to increase from undetectable levels to concentrations of $3.5 \times 10^{4} \mathrm{ml}^{-1}$ as bacteria declined in number. In later experiments, the inoculum was passed twice through $0.6 \mu \mathrm{m}$ filters, effectively removing all flagellates and eliminating the bacterial declines seen previously. In both the 0.2 and $0.02 \mu \mathrm{m}$ filtered water, bacterial growth proceeded at similar rates and concentrations of bacteria reached approximately the same level,

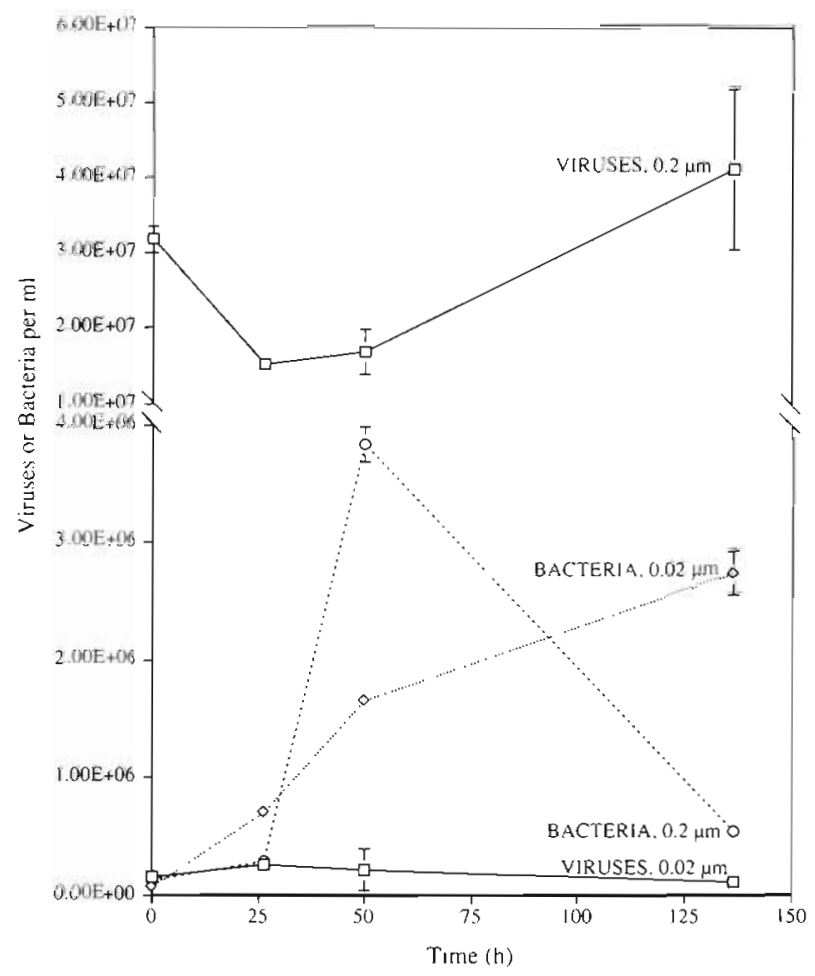

Fig. 1 Abundance of viruses and bacteria in seawater cultures started with 0.02 and $0.2 \mu \mathrm{m}$ filtered seawater, $3 \%(\mathrm{v} / \mathrm{v})$ inoculum of $0.6 \mu \mathrm{m}$ filtered seawater (passed once through filter), and incubated in the dark at $19^{\circ} \mathrm{C}$. Error bars are mean \pm $95 \%$ confidence intervals of duplicate subsamples. Heterotrophic flagellates were noticeably abundant in the $0.2 \mu \mathrm{m}$ filtered sample at $136 \mathrm{~h}$. Experiment started on April 11, 1993 


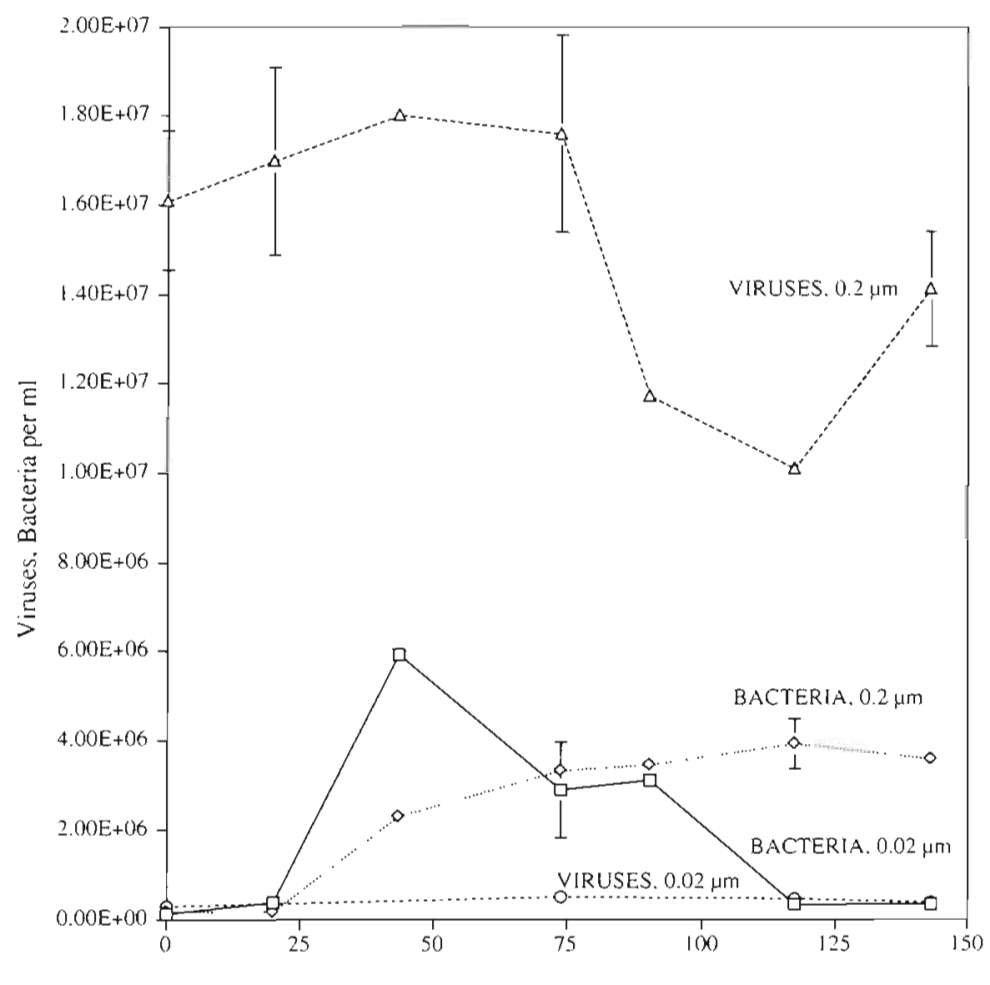

Time (h)

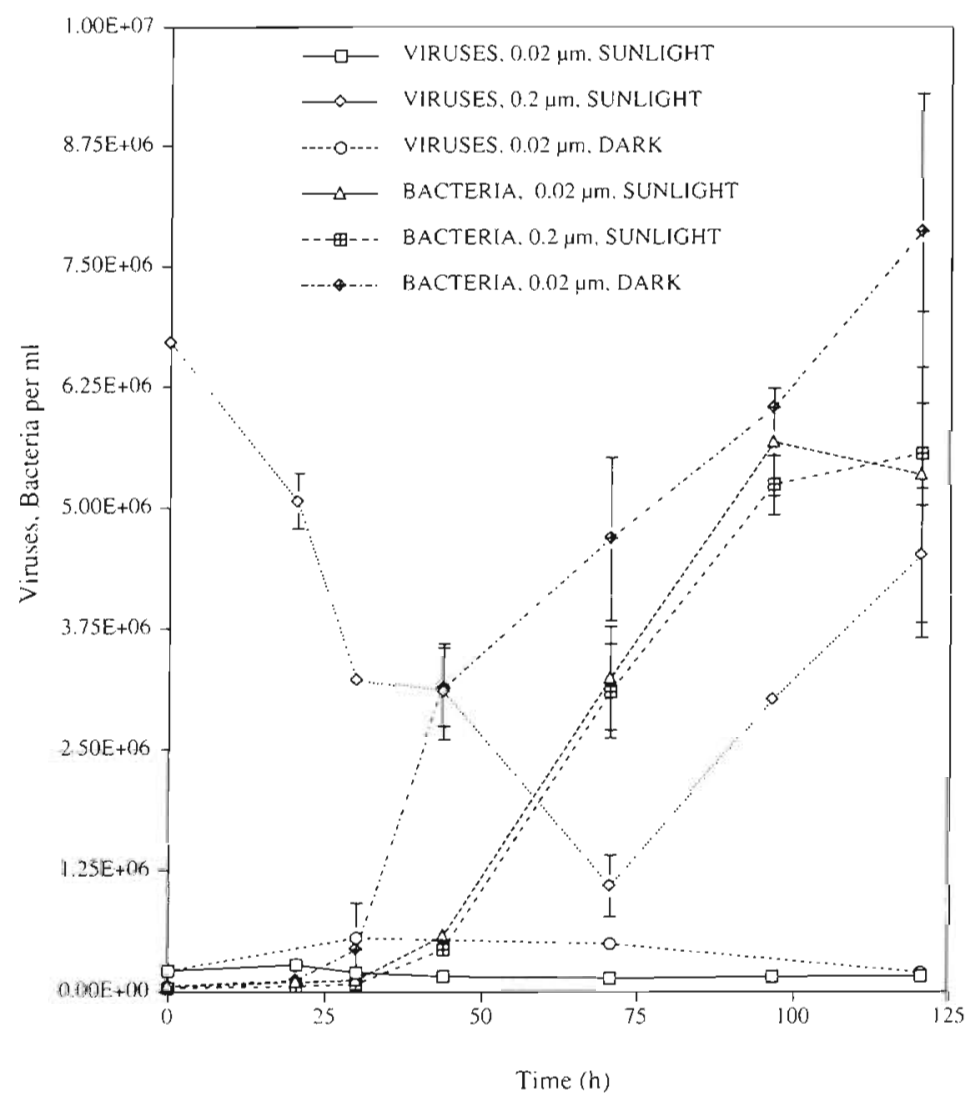

Fig. 2. Abundance of viruses and bacteria in seawater cultures started with 0.02 and $0.2 \mu \mathrm{m}$ filtered seawater, $3 \%(\mathrm{v} / \mathrm{v})$ inoculum of $0.6 \mu \mathrm{m}$ filtered seawater (passed once through filter), and incubated in the dark at $19^{\circ} \mathrm{C}$. Error bars are mean $\pm 95 \%$ confidence intervals of duplicate subsamples. Heterotrophic flagellates were noticeably abundant in the $0.02 \mu \mathrm{m}$ filtered sample at 73 h. Experiment started on May 4, 1993
Fig. 3. Abundance of viruses and bacteria in seawater cultures started with 0.02 and $0.2 \mu \mathrm{m}$ filtered seawater, $3 \%(\mathrm{v} / \mathrm{v})$ inoculum of $0.6 \mu \mathrm{m}$ filtered seawater (passed twice through filter), and incubated at $19^{\circ} \mathrm{C}$ in natural sunlight with a darkincubated control. Error bars are mean $\pm 95 \%$ confidence intervals of duplicate subsamples. Experiment started on July 18, 1993 
Fig. 4. Abundance of viruses and bacteria in seawater cultures started with 0.02 and $0.2 \mu \mathrm{m}$ filtered seawater, $3 \%(\mathrm{v} / \mathrm{v})$ inoculum of $0.6 \mu \mathrm{m}$ filtered seawater (passed twice through filter), and incubated in the dark at $19^{\circ} \mathrm{C}$. The $0.02 \mu \mathrm{m}$ filtered sample was split at $43 \mathrm{~h}$ and one part exposed to sunlight for $35 \mathrm{~min}$ before continuing incubation in the dark. The other part remained in the dark. Error bars are mean $\pm 95 \%$ confidence intervals of duplicate subsamples. Arrow: time at which sunlight pulse took place. Experiment started on August 25, 1993

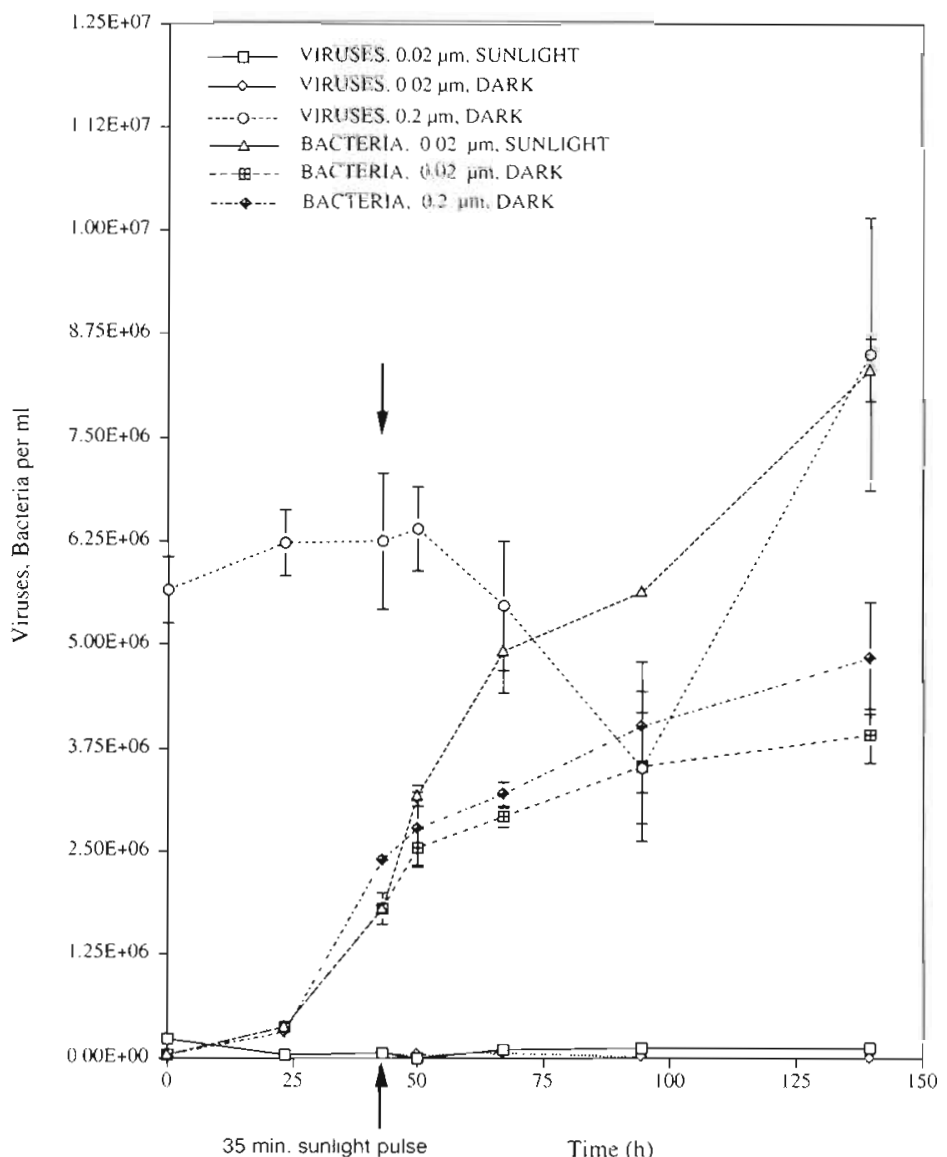

abundances of bacteria at the end the experiment were similar, with no decline in numbers observed, as the problem of flagellate grazing was eliminated by double $0.6 \mu \mathrm{m}$ filtrations.

With all 4 inoculation sizes, viruses were observed to decline during the first $24 \mathrm{~h}$ of sampling at a rate of ca 20 to $50 \% \mathrm{~d}^{-1}$ (Fig. 5). The occurrence of a rebound in number was dependent upon the initial viral abundance. At initial levels of ca $5 \times 10^{5} \mathrm{ml}^{-1}$ or less, viral numbers did not recover. At initial levels of ca $1.3 \times$ $10^{6} \mathrm{ml}^{-1}$ or more, viral abundances were observed to rebound. The final concentration of viruses was dependent on the initial abundance. Timing of the recovery was also dependent on the initial abundance, occurring sooner with the larger inoculation.

\section{Effect of sunlight on viral and bacterial dynamics}

In order to determine if lysogenic virus production could be induced by natural UV or visible irradiance, a $0.02 \mu \mathrm{m}$ filtered sample was incubated in direct sunlight. The same experiment also contained a $0.02 \mu \mathrm{m}$ filtered dark-incubated control and a $0.2 \mu \mathrm{m}$ sunlight-
Bacteria grew at similar rates independent of initial size of inoculation, although bacteria in larger inoculated cultures lagged slightly (Fig. 5). Exponential growth ended after 45 to $70 \mathrm{~h}$ in all cases. The final 


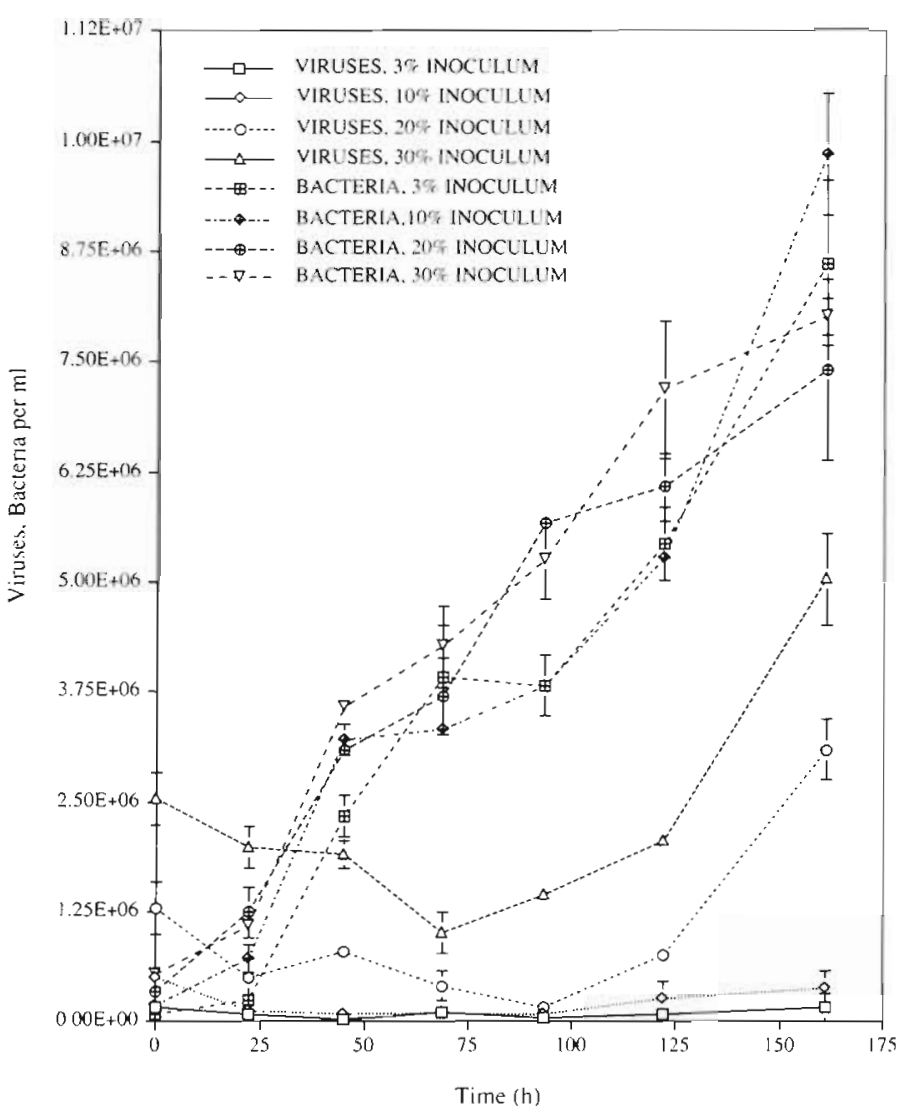

Fig. 5. Abundance of viruses and bacteria in seawater cultures started with 0.02 filtered seawater and 3,10 , 20 , and $30 \%(\mathrm{v} / \mathrm{v})$ inoculum of $0.6 \mu \mathrm{m}$ filtered seawater (passed twice through filter), and incubated in the dark at $19^{\circ} \mathrm{C}$. Error bars are mean $\pm 95 \%$ confidence intervals of duplicate subsamples. Experiment started on September 5, 1993

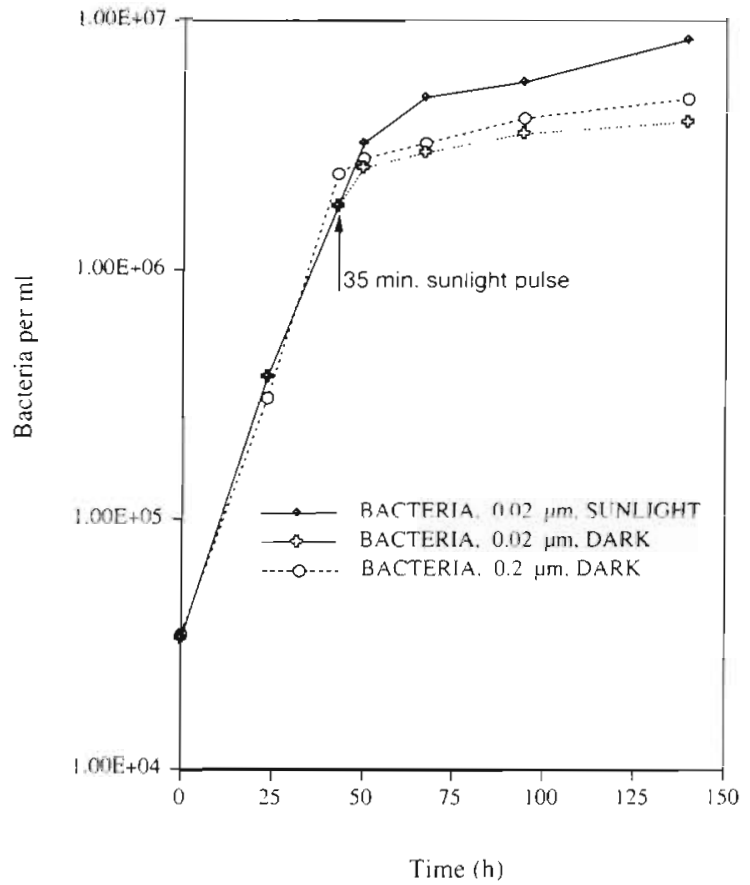

Fig. 6. Semilog plot of abundance of bacteria in seawater cultures shown in Fig. 4. Numbers are means of duplicate samples incubated sample. In both sunlight-incubated samples, exponential bacterial growth was initiated ca $10 \mathrm{~h}$ after the dark sample (Fig. 3), with no significant differences in growth rate until the last time point, where the $0.02 \mu \mathrm{m}$ filtered sample declined. Viral numbers in both the sunlight-incubated and dark-incubated $0.02 \mu \mathrm{m}$ filtered samples were not observed to change significantly. In the $0.2 \mu \mathrm{m}$ filtered sample, viral numbers decreased initially at a rate of ca $50 \% \mathrm{~d}^{-1}$ (Fig. 3 ). The rate of decline decreased at $30 \mathrm{~h}$, and at $70 \mathrm{~h}$ the viruses started to recover. Initial concentrations were not reached by the end of the experiment.

In another experiment, a $0.02 \mu \mathrm{m}$ filtered sample was incubated in the dark and, while the bacteria were growing exponentially (Fig. 6), split in half, one half being subsequently exposed to noon sunlight for $35 \mathrm{~min}$, the other retained in the dark. Bacteria in the sunlight-pulsed sample reached significantly greater abundances (Fig. 4) than in either the dark sample or a $0.2 \mu \mathrm{m}$ filtered dark sample in the same experiment. Virus numbers did not change significantly throughout the experiment in either of the $0.02 \mu \mathrm{m}$ filtered samples. In the $0.2 \mu \mathrm{m}$ filtered sample, virus numbers fluctuated throughout the experiment, ending up at a greater abundance than at the initial time point. 


\section{Bacterial cell morphology}

Cell morphologies were compared in 3 samples at the $94 \mathrm{~h}$ time point in the experiment started on August 24, 1993 (Fig. 4), The contribution of each morphology to the total bacterial assemblage did not vary much between treatments although a reduction in long and medium rods, as well as a significant increase in small cocci, was seen in the $0.2 \mu \mathrm{m}$ filtered sample.

\section{DISCUSSION}

\section{Virus production}

The occurrence of virus production via lytic infection requires a random encounter to occur between a host and phage, as well as a subsequent successful infection. Three factors governing the incidence of lytic infection are: (1) concentration of the host, (2) concentration of the phage, and (3) the rate at which infectivity is lost by the viruses. Lytic infection can be sustained only if the average time for successful encounter with a host is less than the average time for loss of infectivity by the virus.

Recently it has been suggested that virus production in marine environments occurs predominantly through the induction of temperate viruses in lysogenic bacteria, with the infectious state of free phages being too short for efficient lytic production to occur (Bratbak et al. 1990, 1992, Heldal \& Bratbak 1991, Thingstad et al. 1993). Since lysogenic production does not require immediate infection, this hypothesis predicts that the initial concentration of viruses in seawater cultures is not a factor in the establishment of an abundant free virus assemblage. Rather, viruses would be produced through the induction of temperate bacteriophage during the growth of lysogenic bacteria.

The results from our early experiments (Figs. $1 \& 2$ ) indicate that seawater with low initial abundance of viruses had no significant increase in phage concentration throughout the incubation. In these samples, virus production either did not occur or proceeded at a rate too low to lead to the accumulation of free viruses. Viral abundance in seawater cultures with high initial viral, but low bacterial abundances declined initially, but increased after bacterial abundances increased. These results show that a threshold population of free viruses was necessary to initiate the production of viruses by the bacteria in these samples. This suggests that the majority of bacteriophage production was lytic, requiring encounters between infectious viruses and their hosts. Since there was little or no production of viruses at low abundances, lysogenic production was insignificant.
It has been demonstrated that production of temperate viruses by lysogenic bacteria can be induced by factors such chemical agents and exposure to UV light (Ackermann \& DuBow 1987). It is reasonable to ask if we might have excluded a natural lysogen-inducing agent. Our seawater cultures were grown in freshly filtered seawater which should include dissolved chemical agents present in the original samples. Even though the UV wavelengths present in surface solar radiation (typically $>305 \mathrm{~nm}$ ) are not thought to be very active in lysogen induction, we were concerned that we may have excluded any natural solar radiationcaused induction by growing the initial seawater cultures in the dark. Therefore, some seawater cultures were incubated for several days in direct sunlight. Results indicated that production was again dependent on the initial virus concentration and did not occur significantly in seawater with low initial viral abundances (Fig. 3). Suttle \& Chen (1992) observed that viral decay rates are much higher with exposure to sunlight. If decay rates were high enough in the samples with low initial virus concentrations, lysogenic production would not lead to an increase in viral abundance and would therefore be undetectable by our method. However, in the sample with higher initial viral numbers, viral abundance increased after an initial drop, implying that lytic bacteriophage production was occurring faster than virus decay and was again responsible for the majority of virus production. To minimize decay of viruses by sunlight, in another experiment the seawater culture was exposed to a pulse of sunlight rather than to continuous irradiance. Again, there was no accumulation of viruses in the sample with low initial concentration, indicating that lysogenic virus production was insignificant. Therefore, neither the oceanderived dissolved organic matter nor natural solar radiation seemed to induce lysogens in our seawater cultures. However, it is possible that there are shortlived lysogen-inducing agents, such as phytoplanktonproduced antibiotics, which may be present in natural communities but not in our seawater cultures. It seems unlikely that this is a significant source of lysogen induction in natural marine environments, although we do not know. Another possibility is that the filtration steps selectively removed lysogens from the samples or caused lysogen induction immediately, when it would be undetectable due to extremely low concentrations. However, given the range in bacterial cell size which grew in the cultures, selective removal of lysogens also seems unlikely.

Viral infection of a host bacterium is dependent on a random encounter between the virus and host, the encounter rate increasing with an increase in viral or bacterial numbers (Tolmach 1957, Schwartz 1976, Murray \& Jackson 1992). This was demonstrated by 
Wiggins \& Alexander (1985), when they observed that a minimum bacterial density is required for bacteriophage replication in single culture systems. In seawater cultures with high initial viral abundances, viral numbers did not increase initially. Because bacterial concentrations were low initially, infection was unable to proceed, probably until the bacteria reached an abundance where a random encounter between a host and virus was possible within the time that viral infectivity was retained. Steward et al. (1992b) observed a similar initial decline in viral numbers in seawater cultures with initial viral abundances of ca $7 \times 10^{6} \mathrm{ml}^{-1}$ The initial decline in viral abundance (Figs. 1, 3 \& 5) was probably due to decay before production could proceed. In samples with low initial concentrations, viral infectivity was probably lost before the hosts could reach a concentration high enough for a successful encounter.

In order to determine an approximate minimal concentration of a mixed assemblage of natural viruses for initiation of infection, filtered seawater was inoculated with different sizes of inocula ranging from 3 to $30 \%$ $\mathrm{v} / \mathrm{v}$. Net virus production occurred sooner and at lower bacterial concentrations in seawater with a higher initial number of viruses (Fig. 5). When the initial concentration of viruses was $5.06 \times 10^{5} \mathrm{ml}^{-1}$ or less, numbers did not increase significantly throughout the incubation. Kokjohn et al. (1991) observed bacteriophage infection in single culture systems at host and phage densities of $10^{2} \mathrm{CFU} \mathrm{ml} \mathrm{m}^{-1}$ and $2 \times 10^{2}$ infectious centers $\mathrm{ml}^{-1}$. In our seawater cultures, we had no way of determining a minimal density for infection in individual host and phage systems because both viral and bacterial communities were treated as a whole, with no differentiation of individual species. Initial concentrations of $1.3 \times 10^{6}$ viruses $\mathrm{ml}^{-1}$ and greater did facilitate production and accumulation of viruses after an initial drop, as bacterial numbers increased to a level (ca 4.0 to $6.0 \times 10^{6}$ bacteria $\mathrm{ml}^{-1}$ ) where an encounter with an infectious virus was probable. The viral densities required for lytic infection in our experiments may be higher than in natural seawater due to the low initial abundances of bacteria.

The bacterial densities required for lytic virus production in our experiments were higher than many of those observed in natural seawater samples. This could be misinterpreted as an indication that lytic production is unlikely in the natural marine environment; however, virus production is strongly dependent on virus densities as well. A comparison of Figs. 1 \& 5 indicates that at high virus densities, lower bacterial densities are sufficient for virus production. An indication of combined virus and bacterial densities required for lytic infection is the product of viral and bacterial concentrations at the time points in our incubations before viruses were observed to increase. Because encounter rates are dependent on both these concentrations (Murray \& Jackson 1992), infection is proportional to this product. The average value for this product in our experiments was $4.2 \pm 2.4 \times 10^{12}$, the minimum being $9.85 \times 10^{11}$. The requirement in our experiments of high bacterial densities before virus production can take place is probably due to the artificially low virus numbers early in the incubations. Natural seawater samples have been reported to contain viruses at 5 to $10 \times$ higher concentrations than bacteria (Proctor et al. 1988, Bergh et al. 1989, Børsheim et al. 1990, Proctor \& Fuhrman 1990, Cochlan et al. 1993, Paul et al. 1993). Therefore even at low, natural, surface-layer bacterial densities of ca $3 \times 10^{5}$ or greater, lytic infection could occur, if we can extrapolate our results to these systems.

Bacteriophage infection requires an encounter between a bacterial virus and its specific bacterial host. The probability of a successful encounter is therefore dependent on the abundances of individual species within the bacterial community. At this time, these are not known. As species diversity increases, the proportion of each species contribution to total bacterial abundance decreases. This will decrease the likelihood of an encounter between a bacteriophage and its specific host and greater total abundances of both viruses and bacteria will be required for lytic production. If our seawater cultures mimic natural systems they would have similar abundances of individual bacterial species. It is, however, possible that natural systems could have greater or lesser species diversity. It is therefore necessary to determine quantitative bacterial species composition of these systems before a conclusive extrapolation of experimental results to natural marine environments can be made.

Viruses in $0.2 \mu \mathrm{m}$ filtered samples reached abundances similar to those in the unfiltered seawater in only 1 case (Fig. 1). This suggests that not all host/virus combinations from the original sample were present in the cultures. There are several possible explanations for this: (1) virus loss processes were different in the cultures than in natural seawater; (2) host bacteria were excluded from the sample during filtration of the inoculum or were out-competed by faster-growing bacteria; (3) host bacteria were killed off by viruses, which were very abundant initially relative to bacterial concentrations, before they could grow up and produce significant numbers of viruses; (4) the viruses specific to a bacterial host lost their infectivity before the host reached sufficient levels for an encounter to be probable. If this last occurred, the potential host would reproduce without the pressure of viral infection, leaving a subset of the bacterial community virusfree. An indication that the presence of viruses can 
lead to a shift in the make-up of the bacterial community might be a variation in dominant bacterial cell morphologies between samples. We computed the relative abundances of bacteria in 10 morphology classes based on size and shape at the $94 \mathrm{~h}$ time-point for the 3 treatments shown in Fig. 4. Most morphology classes showed no observable overall changes between the 3 samples, although viruses may have influenced the significant changes $195 \%$ confidence, duplicate samples, $n>200$ ) observed in 3 of the morphology classes. However, because cell size can vary depending on growth state (Donachie 1968, Donachie et al. 1976, Trueba \& Woldringh 1980), and bacterial speciation is often visually indistinguishable, cell morphology provides potentially ambiguous information regarding the community composition.

In all the $0.2 \mu \mathrm{m}$ filtered samples, viral abundances were shown to be dynamic, indicating a continuous removal and production of viruses in the seawater. But, where there were increases in the number of viruses, there was no corresponding decrease in bacteria. Because bacteriophages have very specific hosts and may only be controlling a portion of the bacterial community, rapidly growing bacteria could mask any effect of virus-induced mortality. For example, the viruses in the $30 \%$ inoculum (Fig. 5) increased by ca $3 \times 10^{6} \mathrm{ml}^{-1}$ between Hours 120 and 160 . Consequently, assuming an average burst size of 50 (Heldal \& Bratbak 1991) and no removal of viruses over this time, a minimum mortality of ca $6 \times 10^{4}$ bacteria $\mathrm{ml}^{-1}$ would have occurred to produce this increase. This is only $1 \%$ of the bacteria, a decrease which would be undetectable due to the growth of uninfected bacteria over this period. However, adding a consideration of the potential rapid destruction of viruses, the bacterial mortality could be much higher.

\section{Influence of viruses on bacterial growth}

In samples where viruses did not increase, there was little variation in the pattern and level of bacterial growth compared with samples where viral production was significant. However, in all these samples, bacteria multiplied to levels ca 3 times those in the corresponding unfiltered samples, indicating that the balance between bacterial production and removal had been altered. Experiments started on May 4, 1993 and June 1, 1993 (Figs. 1 \& 2) did not exclude heterotrophic nanoflagellates, which were detectable after several days, and these samples had significantly decreased bacterial abundances, indicating that grazing can be strong limiting factor. Grazers are less discriminatory in the bacteria they consume than viruses are in the bacteria they infect. Virus production can only occur as long as the specific host is present at a sufficient abundance, whereas grazers can continue to consume bacteria until the total bacterial abundances are too low to support their growth.

An unexpected observation can be seen in the experiment where a pulse of noontime sunlight in the $0.02 \mu \mathrm{m}$ filtered sample led to a significant increase in bacterial abundance over both the 0.2 and $0.02 \mu \mathrm{m}$ filtered dark-incubated samples (Figs. $4 \& 6$ ). The irradiance may have led to photooxidation of high molecular weight, dissolved organic carbon, releasing biologically labile compounds (Kieber et al. 1989), which subsequently increased bacterial production. An alternate explanation may be that the pulse caused a species shift to UV-resistant bacteria, decreasing competition between different bacterial species.

\section{Ecological implications}

The findings in this study suggest that the majority of bacteriophage production in Santa Monica Pier seawater over the 5 mo period of sampling is via the lytic infection cycle. Relatively high viral abundances were required for virus production to occur in seawater cultures. Considering the high rates of bacteriophage infectivity decay found by Suttle \& Chen (1992), Fuhrman \& Suttle (1993), and Fuhrman et al (1993) and rapid rates of viral destruction (Heldal \& Bratbak 1991), phage production and, consequently, viralinduced mortality must also be high to maintain the observed high viral abundances.

The dominance of the lytic cycle also has implications for virally mediated gene transfer between hosts, which occurs more frequently with temperate phages (Brock \& Madigan 1991). A low incidence of lysogeny would lessen the chances of such transfer.

In oligotrophic waters, lysogenic reproduction may be relatively more important than lytic production. Bacteria under severe nutrient limitations release fewer viruses and have longer latent periods (Kokjohn et al. 1991). Viruses (Cochlan et al. 1993) and bacteria (Fuhrman et al. 1989) in these environments are at lower abundances than in coastal surface waters, with a reduced probability of an encounter between host and virus (Murray \& Jackson 1992). Boehme et al. (1993) measured viral and bacterial numbers in surface, mid and deep waters in a transect from Tampa Bay, Florida, USA, to open ocean waters in the Gulf of Mexico. Using the concentrations they reported to determine the product of virus and bacteria, we found that the value obtained for all the surface waters was above our threshold value of $10^{12}$, which suggests that lytic infection could occur. The values for mid and deep waters at the 5 sites furthest from the coast fell below 
$10^{12}$. This, in combination with the observation of low viral production rates in oligotrophic waters by Steward et al. (1992a), suggests that infectious spread of viruses may not be prevalent in these environments, necessitating lysogenic production of viruses or perhaps lytic production in enriched microzones. Before it is possible to fully understand and predict the type of virus production that is prevalent in a given marine environment, it is important that information on the quantitative bacterial species compositions be determined.

Acknowledgements. The authors thank R. T Noble, $\mathrm{C} . \mathrm{H}$. Thai, A. Vicente, and J. Griffith for assistance with virus and bacterial counts, and Drs G. Bratbak, W. P. Cochlan, R. Zimmer and R. C. Dugdale for reviewing this manuscript. This work was supported by a grant from USC Sea Grant and NSF grant \# OCE 9218234.

\section{LITERATURE CITED}

Ackermann, H.-W., DuBow, M. S. (1987). Viruses of prokaryotes, Vol. 1, General properties of bacteriophages. CRC Press, Boca Raton

Ammerman, J. W., Fuhrman, J. A., Hagström, \&., Azam, F. (1984). Bacterioplankton growth in seawater: I. Growth kinetics and cellular characteristics in seawater cultures. Mar. Ecol. Prog. Ser. 18: 31-39

Bergh, Ø., Børsheim, K. Y., Bratbak, G., Heldal, M. (1989). High abundance of viruses found in aquatic environments. Nature 340: 467-468

Boehme, J., Frischer, M. E., Jiang, S. C., Kellogg, C. A., Pichard, S., Rose, J. B., Steinway, C. Paul, J. H. (1993). Viruses, bacterioplankton, and phytoplankton in the southeastern Gulf of Mexico: distribution and contribution to oceanic DNA pools. Mar. Ecol. Prog. Ser. 97: 1-10

Bersheim, K. Y., Bratbak, G., Heldal, M. (1990). Enumeration and biomass estimation of planktonic bacteria and viruses by transmission electron microscopy. Appl. environ. Microbiol. 56: 352-356

Bratbak, G., Heldal, M., Norland, S., Thingstad, T F. (1990) Viruses as partners in spring bloom microbial trophodynamics. Appl. environ. Microbiol. 56: 1400-1405

Bratbak, G., Heldal, M., Thingstad, T F., Riemann, B. Haslund, O. H. (1992). Incorporation of viruses into the budget of microbial C-transfer. A first approach. Mar Ecol. Prog. Ser. 83: 273-280

Brock, T D., Madigan, M. T (1991). Biology of microorganisms. Prentice Hall, Englewood Cliffs, NJ

Cochlan, W. P., Wikner, J., Steward, G. F., Smith, D. C., Azam, F. (1993). Spatial distribution of viruses, bacterla and chlorophyll a in neritic, oceanic and estuarine environments. Mar. Ecol. Prog. Ser. 92: 77-87

Donachie, W. D. (1968). Relationship between cell size and time of initiation of DNA replication. Nature 219: $1077-1079$

Donachie, W. D., Begg, K. J., Vicent, M. (1976). Cell length, cell growth, and cell division. Nature 264: 328-333

Ferguson, R. L., Rublee, P. (1976). Contribution of bacteria to standing crop of coastal plankton. Limnol. Oceanogr. 21 $141-145$

Fuhrman, J. A. (1992). Bacterioplankton roles in cycling of organic matter: the microbial food web. In: Falkowski, P. G., Woodhead, A. D. (eds.) Primary productivity and biogeochemical cycles in the sea. Plenum Press, New York, p. 361-383

Fuhrman, J. A., Sleeter, T D., Carlson, C. A., Proctor, L. M (1989). Dominance of bacterial biomass in the Sargasso Sea and its ecological implications. Mar. Ecol. Prog. Ser 57: $207-217$

Fuhrman, J. A., Suttle, C. A. (1993). Viruses in marine planktonic systems. Oceanography 6: 51-63

Fuhrman, J. A., Wilcox, R. M., Noble, R. T., Law, N. C. (1993) Viruses in marine food webs. In: Guerrero, R., Pedrós-Alió C. (eds.) Trends in microbial ecology. Spanish Society for Microbiology, Barcelona, p. 295-298

Gerba, C. P., Goyal, S. M. (1982). Methods in environmental virology. Marcel Dekker, Inc., New York

Heldal, M., Bratbak, G. (1991). Production and decay of viruses in aquatic environments. Mar. Ecol. Prog. Ser. 72 $205-212$

Hobbie, J. E., Daley, R. J., Jasper, S. (1977). Use of Nuclepore filters for counting bacteria by fluorescence microscopy Appl. environ. Microbiol. 33: 1225-1228

Kapuscinski, R. B., Mitchell, R. (1980). Processes controlling virus inactivation in coastal waters. Water Res. 14: $363-371$

Kieber, D. J., McDaniel, J. A., Mopper, K. (1989). Photochemical source of biological substrates in seawater: implications for carbon cycling. Nature 341: 637-639

Kokjohn, T A., Sayler, G. S., Miller, R. V. (1991). Attachment and replication of $P_{\text {seudomonas aeruginosa bacterio- }}$ phages under conditions simulating aquatic environments. J. gen. Microbiol. 137: 661-666

Moebus, K. (1987). Ecology of marine bacteriophages. In Goyal, S. M., Gerba, C. P., Bitton, G. (eds.) Phage ecology. Wiley, New York, p. 137-156

Moebus, K. (1992). Further investigations on the concentrations of marine bacteriophages in the water around Helgoland, with reference to the phage-host systems encountered. Helgoländer Meeresunters. 46: 275-292

Murray, A. G., Jackson, G. A. (1992). Viral dynamics: a model of the effects of size, shape, motion and abundance of single-celled planktonic organisms and other particles. Mar. Ecol. Prog. Ser. 89: 103-116

Paul, J. H., Jiang, S. C., Rose, J. B. (1991). Concentration of viruses and dissolved DNA from aquatic environments by vortex flow filtration. Appl. environ. Microbiol. 57(8): $2197-2204$

Paul, J. H., Rose, J. B., Jiang, S. C., Kellogg, C. A., Dickson, L. (1993). Distribution of viral abundance in the reef environment of Key Largo, Florida. Appl, environ. Microbiol. 59: $718-724$

Proctor, L. M., Fuhrman, J. A. (1990). Viral mortality of marine bacteria and cyanobacteria. Nature 343: 60-62

Proctor, L. M., Fuhrman, J. A. (1991). Roles of viral infection in organic particle flux. Mar. Ecol. Prog. Ser. 69: 133-142

Proctor, L. M., Fuhrman, J. A., Ledbetter, M. C. (1988). Marine bacteriophages and bacterial mortality. EOS Trans. Am. Geophys. Union 69: 1111-1112

Schwartz, M. (1976). The adsorption of coliphage Lambda to its host: effect of variation in the surface density of receptor and in phage-receptor affinity. J. molec. Biol. 103: $521-536$

Spencer, R. (1960). Indigenous marine bacteriophages. J. Bacteriol. 79:614

Steward, G. F., Wikner, J., Cochlan, W. P., Smith, D. C., Azam, F. (1992a). Estimation of virus production in the sea: II Field results. Mar. microb. Food Webs 6(2): 79-90

Steward, G. F., Wikner, J., Smith, D. C., Cochlan, W. P., Azam, F. (1992b). Estimation of virus production in the 
sea: I. Method development. Mar microb. Food Webs $6(2): 57-78$

Suttle, C. A., Chen, F. (1992). Mechanisms and rates of decay of marine viruses in seawater. Appl. environ. Microbiol. 58: $3721-3729$

Suttle, C. A., Chen, F., Chan, A. M. (1992). Marine viruses: decay rates, diversity and ecological imolications. In Nash, C. C. Il (ed.) International Marine Biotechnology Conference 'IMBC-91': Short Communications of the Invited Lectures Developments in Microbiology. W. Brown Co., Dubuque, IA, p. 153-163

Thingstad, T F., Heldal, M., Bratbak, G., Dundas, I. (1993) Are viruses important partners in pelagic food webs? Trends Ecol. Evol. 8(6): 209-213

Tolmach, L. J. (1957). Attachment and penetration of cells by

This article was submitted to the editor viruses. Adv. Virus Res. 4:63-110

Torrella, F., Morita, R. Y (1979). Evidence by electron micrographs for a high incidence of bacteriophage particles in the waters of Yaquina Bay, Oregon. Ecological and taxonomic implications. Appl. environ. Microbiol. 37: 774-778

Trueba, F. J., Woldringh, C. L. (1980). Changes in cell diameter during the division cycle of Escherichia coli. J. Bacteriol. 142: 869-878

Wiggins, B. A., Alexander, M. (1985). Minimum bacterial density for bacteriophage replication: implications for significance of bacteriophages in natural ecosystems. Appl. environ. Microbiol. 49: 19-23

Wommack, K. E., Hill, R. T., Kessel, M., Russek-Cohen, E., Colwell, R. R. (1992). Distribution of viruses in Chesapeake Bay. Appl. environ. Microbiol. 58: 2965-2970

Manuscript first received: December 14, 1993

Revised version accepted: August 11, 1994 